\title{
PENGARUH PROFITABILITAS DAN UKURAN PERUSAHAAN \\ TERHADAP PENGUNGKAPAN CSR DENGAN ISLAMI SOSIAL REPORTING INDEKS (STUDI EMPIRIS PADA JAKARTA ISLAMIC INDEX)
}

\author{
Marheni
}

IAIN Syaikh Abdurrahman Siddik Bangka Belitung

\begin{abstract}
The objectives of this study included: a) To analyze the effect of profitability on ISR disclosures; b) To analyze the effect of company size on ISR disclosures; c) To analyze the effect of profitability, firm size, on ISR Disclosure simultaneously. The population in this study are all companies listed in the Jakarta Islamic Index (JII) for the 2014-2016 period. The variables used in this study include Dependent variable (Y) is Islamic Social Reporting (ISR) (Y) and the independent variable (X) is profitability (X1) and firm size (X2). The method of data analysis uses descriptive statistical analysis and multiple linear regression analysis. Haisl research shows that profitability has a statistically significant effect on ISR, meaning that any increase or decrease in profitability affects the increase in ISR; the size of the company statistically has no effect on ISR, meaning that any increase or decrease in the variable size of the company has no effect on the increase and decrease in ISR.
\end{abstract}

Keywords: Profitability, Company size, ISR, JII

\section{Pendahuluan}

Keberadaan sebuah perusahaan di tengah-tengah masyarakat selain memberikan aspek positif juga dapat memberikan aspek negatif. Perusahaan dianggap sebagai lembaga yang dapat memberikan banyak keuntungan bagi 
masyarakat. Perusahaan dapat memberikan kesempatan kerja, menyediakan barang dan jasa yang diperlukan oleh masyarakat untuk dikonsumsi. Perusahaan juga menguntungkan negara karena membayar pajak, memberi sumbangan dan lain-lain. Karena itu perusahaan mendapat izin untuk dapat beraktivitas dengan leluasa. Setiap perusahaan didirikan dengan maksud dan tujuan agar dapat memenuhi kebutuhan masyarakat yang beraneka ragam. Agar dalam memenuhi kebutuhan hidupnya, masyarakat dapat lebih mudah mendapatkan apa yang dibutuhkan. Akan tetapi disisi lain perusahaan juga memiliki dampak yang buruk bagi masyarakat, terutama bagi masyarakat sekitar akibat aktivitas bisnis yang dilakukan perusahaan ${ }^{1}$.

Di balik semua aspek positif yang diberikan oleh perusahaan, terdapat hal lain yang menyebabkan keberadaan perusahaan di tengah masyarakat, yaitu untuk mencari keuntungan atau laba yang sebesar-besarnya dari setiap aktivitas produksinya. Dalam upaya mendapatkan laba tersebut, setiap perusahaan selalu berusaha mencari peluang dan kesempatan untuk melakukan sesuatu yang dapat memberikan nilai tambah, dan pada akhirnya jika hal itu dibiarkan tidak terkontrol maka kemungkinan besar yang dapat timbul adalah dampak-dampak negatif yang dapat merugikan lingkungan dan masyarakat ${ }^{2}$. Dampak-dampak tersebut seperti polusi, keracunan, kebisingan, eksploitasi besar-besaran terhadap sumber daya alam, diskriminasi, pemaksaan, kesewenang-wenangan, produksi makanan haram, sampai ke penipuan-penipuan terhadap konsumen seperti penjualan barang dengan kualitas rendah atau barang-barang yang sudah tidak layak pakai lagi (kadaluarsa), dan sebagainya.

Perusahaan yang tumbuh dan berkembang mempunyai tujuan utama yaitu profitabilitas dengan mendapatkan pencitraan dan persepsi yang baik

1 Ariestia, 2010. Pengaruh Pengungkapan Corporate Social Responsibility (pengungkapan informasi CSR) Terhadap Profitabilitas Perusahaan. Jurnal Ekonomi. Fakultas Ekonomi. Universitas Jember, hlm.1

${ }^{2}$ Ibid 
dari para stakeholder. Namun dewasa ini pandangan tersebut bergeser kearah yang lebih kompleks yaitu bagaimana masyarakat sebagai pengguna hasil produksi perusahaan mengakui kredibilitas perusahaan tersebut. Sebab, perusahaan merupakan bagian dari masyarakat dan lingkungan yang keberadaannya tidak lepas darinya. Mengingat hal tersebut maka penting bagi perusahaan untuk turut serta menjaga dan peduli terhadap aspek sosial baik masyarakat maupun lingkungan dimana perusahaan tersebut beroperasi. Konsep ini kemudian berkembang dengan istilah Corporate Sosial Responsibility (CSR). CSR dimaksudkan untuk mendorong dunia usaha lebih etis dalam menjalankan aktivitasnya agar tidak berdampak buruk pada masyarakat dan lingkungan hidupnya, sehingga pada akhirnya dunia usaha akan dapat bertahan secara berkelanjutan ${ }^{3}$.

CSR adalah salah satu faktor penting untuk meningkatkan nilai perusahaan, maka perusahaan perlu mempertimbangkan CSR sebagai salah satu aspek daya tarik bagi investor selain kinerja keuangan perusahaan. Investor cenderung tertarik terhadap informasi sosial yang dilaporkan dalam laporan keuangan, dimana pelaporan keuangan merupakan media bagi manajemen perusahaan dalam memberikan informasi kinerja keuangan entitas yang bermanfaat untuk stakeholders. Selain pelaporan keuangan sebagai media pengungkapan tanggung jawab perusahaan, perkembangan pelaksanaan CSR mendorong perusahaan untuk juga mengungkapkan sebuah laporan yang tidak berpijak pada kondisi keuangan saja tetapi juga menyediakan informasi lingkungan dan sosial yang kemudian disebut laporan berkelanjutan atau sustainability report.

Seiring dengan berkembang pesatnya bisnis berbasis syariah di Indonesia saat ini, ada sebagian perusahaan yang menerapkan CSR dengan menggunakan

3 Kusuma, Tanjung dan Darlis. 2014 "Pengaruh corporate governance dan karakteristik perusahaan terhadap luas pengungkapan corporate social responsibility (CSR) di dalam Sustainability Report". JOM FEKON Vol. 1 No.2 Oktober, hlm.2 
konsep syariah. Konsep CSR dalam Islam menggunakan dasar Al-Qur'an dan Hadist. CSR dalam konsep Islam disebut Islamic Social Reporting (ISR). PT Bursa Efek Indonesia (BEI) bekerjasama dengan PT Danareksa Investment Management (DIM) meluncurkan saham yang dibuat berdasarkan syariah islam yaitu Jakarta Islamic Index (JII). Index ini dianggap menjadi tolak ukur kinerja saham-saham yang berbasis syariah untuk mengembangkan pasar modal syariah. Sesuai dengan peraturan Bapepam-LK Nomor IX.A.13 tentang Penerbitan Efek Syariah hanya perusahaan yang memenuhi syariah islam yang dapat lolos dalam 30 perusahaan yang terdaftar pada Jakarta Islamic Index (JII).

Dalam perkembangan pasar modal saat ini, perusahaan berbasis syariah sangat diminati oleh investor karna dianggap sesuai dengan syariat Islam yaitu bebas dari riba dan hal yang haram lainnya. Faktanya hal tersebut berbanding terbalik dengan kondisi bisnis saat ini, masih belum banyak perusahaan yang mengungkapkan konsep syariah dalam pengelolaannya. Oleh karena itu, perusahaan yang belum mempunyai efek syariah diharapkan menggunakan konsep syariah dalam bisnisnya untuk menjaga persaingan pada pasar modal.

Beberapa penelitian terdahulu yang meneliti faktor yang mempengaruhi pengungkapan Islamic Social Reporting (ISR) yaitu Rosiana dkk (2015) dengan hasil penelitian menyebutkan Ukuran Perusahaan berpengaruh terhadap pengungkapan ISR ${ }^{4}$. Hasil penelitian ini selaras dengan penelitian Othman et al. (2009), ukuran perusahaan secara positif signifikan mempengaruhi tingkat pengungkapan ISR $^{5}$. Perusahaan yang lebih besar adalah perusahaan yang memiliki sumber daya lebih banyak daripada perusahaan yang lebih kecil. Dengan demikian, perusahaan yang lebih besar sudah pasti memiliki pembiayaan, fasilitas, dan sumber daya manusia yang lebih banyak untuk

${ }^{4}$ Rosiana, dkk. 2015. Pengaruh Ukuran Perusahaan, Profitabilitas, Leverage, dan Islamic Governance Score terhadap Pengungkapan ISR. Jurnal Bisnis Manajeme Universitas Tirtayasa: Maluku

5 Othman et al. 2009. Islamic Social Reporting of Listed Companies in Malaysia. International Business and Economic Research Journal. Univ Teknomaya: Malaysia 
dapat melakukan pengungkapan yang lebih sesuai dengan prinsip Islam (Othman et al , 2009). Akan tetapi hasil penelitian tersebut bertentangan dengan Nadliyah $(2016)^{6}$ yang menyatakan bahwa ukuran perusahaan tidak berpengaruh terhadap pengungkapan ISR7.

Profitabilitas yang tinggi cenderung membuat manajemen perusahaan mengungkapkan laporan keuangan yang lengkap, termasuk mengungkapkan tanggung jawab sosialnya. Hal tersebut didukung oleh Ramadhani $(2016)^{8}$ dalam penelitiannya yang menyatakan Profitabilitas berpengaruh terhadap pengungkapan ISR, namun bertentangan dengan hasil penelitian Rosiana dkk (2015) ${ }^{9}$ yang menyatakan sebaliknya.

Tujuan dari dilakukannya penelitian ini antara lain: a) Untuk menganalisis pengaruh profitabilitas terhadap pengungkapan ISR; b) Untuk menganalisis pengaruh ukuran perusahaan terhadap pengungkapan ISR; c) Untuk menganalisis pengaruh pengaruh profitabilitas, ukuran perusahaan, terhadap Pengungkapan ISR secara simultan.

\section{Landasan Teori dan Hipotesis}

\subsection{Islamic Social Reporting (ISR)}

Sejalan dengan makin meningkatnya pelaksanaan Corporate Social Reporting (CSR) dalam dunia bisnis, maka makin meningkat pula keinginan untuk membuat pelaporan sosial atau yang sering disebut dengan social reporting. Banyak pendapat yang menjelaskan mengenai pengungkapan social

6 Nadlifiyah, Ia Fajriyatun, 2016. Pengaruh Ukuran Perusahaan, Umur Perusahaan, Profitabilitas, Dan Likuiditas Terhadap Pengungkapan Islamic Social Reporting (Isr) Pada Bank Umum Syariah (BUS) Di Indonesia Tahun 2010-2014. Thesis, Universitas Airlangga, hlm.1

7 Nadlifiyah, Ia Fajriyatun, 2016. Pengaruh Ukuran Perusahaan, Umur Perusahaan, Profitabilitas, Dan Likuiditas Terhadap Pengungkapan Islamic Social Reporting (Isr) Pada Bank Umum Syariah (BUS) Di Indonesia Tahun 2010-2014. Thesis, Universitas Airlangga, hlm.1

8 Ramadhani. 2016. Pengaruh Ukuran Perusahaan, Profitabilitas, Leverage dan Ukuran Dewan Pengawas Syariah terhadap Pengungkapan ISR. Jurnal Pekan: Jakarta, hlm.1

${ }^{9}$ Rosiana, dkk. 2015. Pengaruh Ukuran Perusahaan, Profitabilitas, Leverage, dan Islamic Governance Score terhadap Pengungkapan ISR. Jurnal Bisnis Manajeme Universitas Tirtayasa: Maluku 
reporting. Social Reporting merupakan perluasan dari sistem pelaporan keuangan yang merefleksikan perkiraan yang baru dan yang lebih luas dari masyarakat sehubungan dengan peran komunitas bisnis dalam perekonomian ${ }^{10}$. Sedangkan dalam social reporting adalah proses untuk mengkomunikasikan efek sosial lingkungan akibat dari tindakan ekonomi yang dilakukan oleh suatu perusahaan kepada masyarakat ${ }^{11}$. Peraturan social reporting dapat diterima oleh beberapa kelompok namun tidak dapat diterima oleh kelompok yang lainnya, hal tersebut dikarenakan kode etik dalam social reporting bersifat relatif ${ }^{12}$. Tidak ada cara yang paling tepat untuk menentukan kode etik yang mana yang paling tepat. Selain itu, identifikasi tanggung jawab sebuah organisasi merupakan suatu masalah karena tanggung jawab terus berubah-ubah setiap waktu Berbeda dengan Islam, Islam telah menjelaskan cukup jelas mengenai hak dan kewajiban bagi individu maupun bagi organisasi berdasarkan Al-Quran dan Hadist. Hal tersebut dikarenakan Islam adalah agama yang secara lengkap mengatur seluruh aspek kehidupan manusia di muka bumi.

Salah satu bentuk akuntabilitas dalam perspektif ekonomi Islam adalah pelaporan tanggung jawab sosial perusahaan yang sesuai dengan prinsip syariah. Dalam ekonomi konvensional, pelaporan tanggung jawab sosial dikenal dengan perpanjangan dari sistem pelporan keuangan yang merefleksikan ekspektasi sosial yang lebih luas sehubungan dengan peran masyarakat dalam ekonomi. Bentuk pelaporan tanggung jawab sosial perusahaan yang sesuai dengan prinsip syariah biasa disebut Islamic Social Reporting (ISR).

${ }^{10}$ Hanifah, M.Mahmud, 2002, Analisis Laporan Keuangan, Yogyakarta : YKPN.

11 Gray, 1987. Social Report, Corporate Social Reporting Accounting \& Accountability. Prestice Journal: USA

12 Lewis, Linda and Jeffrey Unerman. 1999. Ethical Relativism: A Reason for Differences in Corporate Social Reporting. Critical Perspectives on Accounting. Vol. 10, hlm. 521-547 
ISR adalah standar pelaporan kinerja sosial perusahaan-perusahaan yang berbasis syariah. Indeks ini lahir dikembangkan dengan dasar dari standar pelaporan berdasarkan AAOIFI yang kemudian dikembangkan oleh masingmasing peneliti berikutnya. Secara khusus indeks ini adalah perluasan dari standar pelaporan kinerja sosial yang meliputi harapan masyarakat tidak hanya mengenai peran perusahaan dalam perekonomian, tetapi juga peran perusahaan dalam perspektif spiritual. Selain itu indeks ini juga menekankan pada keadilan sosial terkait mengenai lingkungan, hak minoritas, dan karyawan.

\subsection{Teori Stake Holder}

Teori stakeholder mengatakan bahwa perusahaan bukanlah entitas yang hanya beroperasi untuk kepentingan sendiri namun juga harus mampu memberikan manfaat bagi stakeholdernya. Dengan demikian, keberadaan suatu perusahaan sangat dipengaruhi oleh dukungan yang diberikan oleh stakeholder perusahaan tersebut ${ }^{13}$. Asumsi teori stakeholder dibangun atas dasar pernyataan bahwa perusahaan berkembang menjadi sangat besar dan menyebabkan masyarakat menjadi sangat terkait dan memerhatikan perusahaan, sehingga perusahaan perlu menunjukkan akuntabilitas maupun responsibilitas secara lebih luas dan tidak terbatas hanya kepada pemegang saham

Ramizes dalam bukunya Cultivating Peace, mengidentifikasi berbagai pendapat mengenai stakeholder. Friedman mendefinisikan stakeholder sebagai:

"any group or individual who can affect or is affected by the achievment of the organization's objectives. Terjemahan bebasnya adalah sebagai kelompok atau individu yang dapat mempengaruhi dan/atau dipengaruhi oleh suatu pencapaian tujuan tertentu. ${ }^{14}$

\footnotetext{
${ }^{13}$ Ghozali, Imam dan Chariri. 2007. Teori Akuntansi. Semarang : Badan Penerbit, hlm.7

14 Busyra Azheri, 2012. Corporate Social Responsibility; Dari Voluntary Menjadi Mandatory, Rajawali Pers, Jakarta, 2012, hlm. 142.
} 
Biset secara singkat mendefinisikan stakeholders adalah orang dengan suatu kepentingan atau perhatian pada permasalahan tertentu. Sedangkan Grimble and Wellard melihat stakeholders dari segi posisi penting dan pengaruh yang mereka miliki. Dari definisi tersebut, maka stakeholders merupakan keterikatan yang didasari oleh kepentingan tertentu. Dengan demikian, jika berbicara mengenai stakeholders theory berarti membahas hal- hal yang berkaitan dengan kepentingan berbagai pihak.

Hal pertama mengenai teori stakeholder adalah bahwa stakeholder merupakan sistem yang secara eksplisit berbasis pada pandangan tentang suatu organisasi dan lingkungannya, mengenai sifat saling mempengaruhi antara keduanya yang kompleks dan dinamis. Stakeholder dan organisasi saling mempengaruhi, hal ini dapat dilihat dari hubungan sosial keduanya yang berbentuk responsibilitas dan akuntabilitas. Oleh karena itu organisasi memiliki akuntabilitas terhadap stakeholdernya ${ }^{15}$.

Premis dasar dari teori stakeholder adalah bahwa semakin kuat hubungan korporasi, maka akan semakin baik bisnis korporasi. Sebaliknya, semakin buruk hubungan korporasi maka akan semakin sulit. Hubungan yang kuat dengan para pemangku kepentingan adalah berdasarkan kepercayaan, rasa hormat, dan kerjasama. Teori stakeholder adalah sebuah konsep manajemen strategis, tujuannya adalah untuk membantu korporasi memperkuat hubungan dengan kelompok-kelompok eksternal dan mengembangkan keunggulan kompetitif16

Teori stakeholder mengatakan bahwa perusahaan bukanlah entitas yang hanya beroperasi untuk kepentingannya sendiri namun harus memberikan manfaat bagi stakeholdernya. Dengan demikian, keberadaan suatu perusahaan sangat dipengaruhi oleh dukungan yang diberikan oleh stakeholder kepada

15 Nur, Marzully dan Priantinah, Denies. 2012. Analisis Faktor-Fakor yang Mempengaruhi Pengungkapan Corporate Social Responsibility" Jurnal Nominal, Vol I, No I, hlm. 1.

${ }^{16}$ Mardikanto, Totok. 2014. CSR (Corporate Social Responsibility). Bandung: Alfabeta 
perusahaan tersebut. Gray, Kouhy dan Adams mengatakan bahwa kelangsungan hidup perusahaan tergantung pada dukungan stakeholders sehingga aktivitas perusahaan adalah untuk mencari dukungan tersebut. Semakin powerful stakeholder, maka semakin besar usaha perusahaan untuk beradaptasi. Pengungkapan sosial dianggap sebagai bagian dari dialog antara perusahaan dengan stakeholdernya. ${ }^{17}$

\subsection{Profitablitas}

Profitabilitas atau kemampuan memperoleh laba adalah suatu ukuran dalam persentase yang digunakan untuk menilai sejauh mana perusahaan mampu menghasilkan laba pada tingkat yang dapat diterima. Profitabilitas mempunyai arti penting dalam usaha untuk mempertahankan kelangsungan hidup perusahaan dalam jangka panjang karena profitabilitas menunjukkan apakah entitas tersebut mempunyai prospek yang baik di masa yang akan datang ataukah tidak. Dengan demikian, setiap perusahaan akan selalu berusaha meningkatkan profitabilitasnya, karena semakin tinggi tingkat profitabilitas suatu perusahaan maka kelangsungan hidup perusahaan tersebut akan semakin terjamin. Semakin tinggi profitabilitas perusahaan berarti perusahaan memiliki pembiayaan yang lebih untuk mengungkapkan laporan keuangan yang lengkap, yaitu ISR.

Setiap perusahaan akan berusaha untuk meningkatkan kinerja perusahaannya dalam rangka untuk meningkatkan produktivitas perusahaan. Tetapi, selain itu perusahaan juga harus dapat mengadakan efektivitas dan efisiensi dalam melakukan operasional usaha perusahaan. Peningkatan produktivitas dan dilakukannya program efektivitas dan efisiensi merupakan langkah yang diambil perusahaan dalam rangka untuk memperoleh

${ }_{17}$ Handoko, Yunus. 2015. Implementasi Social and Environmental Disclosure dalam Perspektif Teoritis. Jurnal JIBEKA Volume 8 No 1 Februari, hlm.2 
keuntungan (Profit). Kemampuan perusahaan untuk tetap dapat bersaing dalam kompetisi dengan perusahaan-perusahaan lainnya, menuntut perusahaan untuk dapat meningkatkan profitabilitas. Profitabilitas merupakan alat yang digunakan untuk menganalisis kinerja manajemen, tingkat profitabilitas akan menggambarkan posisi laba perusahaan.

Rasio profitabilitas merupakan rasio untuk menilai kemampuan perusahaan dalam mencari keuntungan ${ }^{18}$. Rasio ini juga memberikan ukuran tingkat efektifitas manajemen suatu perusahaan. Hal ini ditunjukkan oleh laba yang dihasilkan dari penjualan dan pendapatan investasi. Manfaat rasio profitabilitas tidak terbatas hanya pada pemilik usaha atau manajemen saja, tetapi juga bagi pihak luar perusahaan, terutama pihak-pihak yang memiliki hubungan atau kepentingan dengan perusahaan.

\subsection{Ukuran Perusahaan}

Ukuran perusahaan diukur dengan total asset perusahaan yang diperoleh laporan keuangan perusahaan. Ukuran perusahaan dapat dilihat oleh investor melalui suatu undikator yang di gambarkan tingkat rasio untuk melakukan suatu investasi atau besaran investasi. Perusahaan yang lebih besar adalah perusahaan yang memiliki sumberdaya lebih banyak daripada perusahaan yang kecil. Dengan demikian, perusahaan yang lebih besar sudah pasti memiliki pembiayan, fasilitas yang besar untuk mengungkapkan laporan keuangannya secara lengkap.

Ukuran perusahaan adalah suatu skala dimana dapat diklasifikasikan besar kecilnya perusahaan menurut berbagai cara antara lain dengan total aktiva, log size, harga pasar saham dan lain-lain. Besar kecilnya perusahaan akan mempengaruhi kemampuan dalam menanggung resiko yang mungkin timbul dari berbagai situasi yang dihadapi perusahaan. Perusahaan besar

18 Kasmir. 2008. Bank dan Lembaga Keuangan Lainnya. Edisi Revisi 2008. Jakarta: PT. Rajagrafindo Persada, hlm.56 
memiliki resiko yang lebih rendah dari pada perusahaan kecil. Hal ini dikarenakan perusahaan besar memiliki kontrol yang lebih baik terhadap kondisi pasar, sehingga mereka mampu menghadapi persaingan ekonomi. Selain itu perusahaan-perusahaan besar mempunyai lebih banyak sumber daya untuk meningkatkan nilai perusahaan karena memiliki akses yang lebih baik terhadap sumber-sumber informasi eksternal dibandingkan dengan perusahaan kecil. Selain itu, ukuran perusahaan turut menentukan tingkat kepercayaan investor ${ }^{19}$. Dengan demikian, ukuran perusahaan berpengaruh terhadap struktur pendanaan yang didasarkan pada kenyataan bahwa semakin besar suatu perusahaan, ada kecenderungan untuk menggunakan jumlah pinjaman yang lebih besar.

\subsection{Pengembangan Hipotesis}

Hipotesis yang dipakai pada penelitian ini adalah sebagai berikut :

\subsubsection{Pengaruh Profitabilitas terhadap Pengungkapan Islamic Social Reporting (ISR)}

Profitabilitas adalah suatu kemampuan perusahaan dalam menghasilkan laba ${ }^{20}$. Semakin tinggi profitabilitas suatu perusahaan berarti semakin tinggi pula kemampuan perusahaan dalam menghasilkan laba, sehingga mempengaruhi tingkat pengungkapan yang dilakukan oleh perusahaan agar dapat menarik minat investor untuk menanamkan modal pada perusahaan. apabila perusahaan sedang mendapatkan keuntungan yang tinggi maka manajer akan termotivasi untuk mengungkapkan informasi rinci dalam rangka mendukung kelanjutan posisi mereka dan remunerasi. Sedangkan ketika keuntungan menurun maka manajer akan memberikan informasi yang kurang dalam rangka menyembunyikan alasan kerugian atau keuntungan yang

${ }^{19}$ Ibid. hlm 4

20 Harahap. 2009. Pengaruh ISR, Ukuran Perusahaan dan Kepemilikan Saham Publik terhadap Profitabilitas pada Perusahaan yang terdaftar di JII. Univ Negeri Islam: Sumatera Utara, hlm.3 
menurun. Oleh karena itu, akan lebih menguntungkan bagi perusahaan untuk melakukan pengungkapan Islamic Social Reporting.

Perusahaan dengan profit yang tinggi akan melakukan pengungkapan Islamic Social Reporting sebagai bentuk akuntabilitas dan transparansi kepada para pemilik modal atas dana-dana yang telah diinvestasikan. Perusahaan melakukan pengungka-pan tanggungjawab sosial tidak hanya menjelaskan mengenai apa saja tindakan perusahaan yang dapat meningkatkan kualitas hidup masyarakat dan lingkungan, tetapi juga pengungkapan mengenai apakah bahwa tindakan operasional, transaksi dan praktik yang dilakukan perusahaan telah Semakin besar ukuran perusahaan maka kemungkinan semakin banyak pula investor yang menanamkan modalnya di perusahaan tersebut. Banyaknya pemegang saham di suatu perusahaan, menandakan bahwa perusahaan tersebut cenderung memiliki permintaan yang lebih akan informasi pelaporan perusahaannya, dan perusahaan seharusnya memiliki kemampuan untuk memberikan informasi yang lebih banyak kepada para pemegang saham.

Perusahaan dengan profit yang lebih tinggi memiliki kecenderungan untuk melakukan intervensi kebijakan ${ }^{21}$. Oleh karena itu, perusahaan tersebut akan terdorong untuk mengungkapkan informasi yang lebih rinci dalam laopran tahunan mereka dalam rangka mengurangi biaya politik dan menunjukkan kinerja keuangan kepada publik. Othman et al. (2009)22 dan Raditya (2012) membuktikan bahwa profitabilitas mempunyai pengaruh positif signifikan terhadap tingkat pengungkapan ISR. Widiawati dan Raharja (2012) ${ }^{23}$ menemukan bahwa Profitabilitas berpengaruh positif dan signifikan terhadap ISR. Penelitian ini membuktikan bahwa perusahaan yang berada pada posisi

${ }^{21}$ Watts, R, L., and Zimmerman, J, L. 1986, Positive Accounting Theory. New. York, Prentice Hall, hlm.132

22 Op.Cit. Othman et al. (2009)

${ }^{23}$ Widiawati, Septi dan Raharja, Surya. 2012. Analisis Faktor-Faktor Yang Mempengaruhi Islamic Social Reporting Perusahaan-Perusahaan Yang Terdapat Pada Daftar Efek Syariah Tahun 2009-2011. Diponegoro Journal Of Accounting Volume 1, Nomor 2, Tahun 2012, hlm. 1-15 
yang menguntungkan akan cenderung mengungkapkan ISR lebih luas dibandingkan perusahaan yang mengalami kerugian, meskipun tidak secara keseluruhan perusahaan yang merugi akan mengungkapkan ISR lebih kecil. Dengan demikian, hipotesis yang akan diajukan berdasarkan uraian di atas:

H1 : Ada pengaruh profitabilitas terhadap ISR

\subsubsection{Pengaruh Ukuran Perusahaan terhadap Pengungkapan Islamic Social Reporting (ISR)}

Ukuran perusahaan merupakan tingkat identifikasi besar atau kecilnya suatu perusahaan. Perusahaan besar biasanya melakukan aktivitas yang lebih banyak dan memiliki dampak yang besar terhadap para stakeholdersnya. Perusahaan yang berukuran lebih besar cenderung memiliki public demand terhadap informasi yang lebih tinggi dibanding perusahaan yang berukuran lebih kecil. Hal ini disebabkan banyaknya jumlah stakeholders pada bank syariah adalah mayoritas beragama islam dimana mereka memiliki kebutuhan pemenuhan informasi kegiatan yang ada pada tempat mereka berinvestasi. Melakukan pengungkapan informasi tanggung jawab sosial secara islami adalah cara untuk memenuhi kebutuhan spiritual perusahaan tidak hanya kepada stakeholdersnya tetapi juga kepada Allah SWT.

Semakin besar ukuran perusahaan, biasanya informasi yang tersedia untuk investor dalam pengambilan keputusan sehubungan dengan investasi dalam perusahaan tersebut semakin banyak ${ }^{24}$. Adanya dugaan bahwa perusahaan kecil akan mengungkapkan lebih rendah kualitasnya dibandingkan dengan perusahaan besar, menurut Buzby ${ }^{25}$ Hasil penelitian Othman et al. (2009)26 dan Raditya (2012) menunjukkan bahwa ukuran perusahaan secara

${ }^{24}$ Raditya, Nurul Amalia Age. 2012. Analisis Faktor-faktor Yang Mempengaruhi Tingkat Pengungkapan Islamic Social Reporting (ISR) Pada Perusahaan Yang Terdaftar di Bursa efek Syariah (DES). Universitas Indonesia: Jakarta, hlm. 1

${ }^{25}$ Hanifah, M.Mahmud, 2002, Analisis Laporan Keuangan, Yogyakarta : YKPN, hlm.2

${ }^{26}$ Op.Cit Othman et al. (2009) 
positif berpengaruh signifikan terhadap tingkat ISR. Widiawati dan Raharja (2012) ${ }^{27}$ menemukan bahwa ukuran perusahaan berpengaruh signifikan dan positif terhadap ISR pada perusahaan manufaktur, perusahaan nonmanufaktur, perusahaan yang menggunakan bank syariah maupun perusahaan yang tidak menggunakan bank syariah selama tahun 2009-2011. Penelitian ini membuktikan bahwa perusahaan yang lebih besar (total aset) memiliki kecenderungan untuk mengungkapkan ISR lebih luas dibandingkan perusahaan yang lebih kecil. Dengan demikian, hipotesis yang akan diajukan berdasarkan uraian di atas:

$\mathrm{H}_{2}$ : Ada hubungan positif antara ukuran perusahaan dan tingkat ISR

\section{Metode Penelitian}

Penelitian ini termasuk penelitian penjelasan atau eksplanatory research. Jenis penelitian ini dengan menggunakan data sekunder yang bersifat kausalitas yaitu penelitian yang mencari penjelasan bentuk hubungan sebab akibat antara beberapa variabel independen dengan variabel dependen. Data yang digunakan adalah data yang diambil dari laporan keuangan tahunan Perusahaan sektor yang masuk dalam Jakarta Islamic Index (JII) periode 20142016. Populasi dalam penelitian ini adalah seluruh perusahaan yang terdaftar di Jakarta Islamic Index (JII) periode 2014-2016. Terdapat sebanyak 30 perusahaan manufaktur yang terdaftar di Jakarta Islamic Index (JII) selama 2014-2016. Sampel merupakan bagian dari populasi yang ingin diteliti. Sampel pada penelitian ini ditentukan berdasarkan purposive sampling yaitu sampel yang dipilih dengan menggunakan pertimbangan dengan kriteria tertentu ${ }^{28}$. Adapun kriteria yang di gunakan dalam penelitian ini yaitu perusahaan yang menerbitkan laporan keuangan secara lengkap selama 2014-2016; dan perusahaan yang berturutturut terdaftar dalam Jakarta Islamic Index (JII) selama 2014-2016.

\footnotetext{
27 Op.Cit. Widiawati dan Raharja

28
} 
Variabel-variabel yang digunakan dalam penelitian ini antara lain variabel Dependen (Y) adalah Islamic Social Reporting (ISR) (Y) dan variabel independen (X) adalah profitabilitas (X1) dan ukuran perusahaan (X2). Variabel Dependen (Y) adalah Islamic Social Reporting (ISR) dijelaskan dengan penggunaan indeks ISR yang dirancang oleh Othman et al. (2009), ini dilakukan pada penelitian Ayu (2010) dan Raditya (2012) yang juga membagi ISR menjadi enam kategori dengan total pengungkapan 43 item indeks pengungkapan. Nilai terbesar (skor) yang dapat diperoleh setiap tahunnya dari laporan pengungkapan perusahaan adalah 43 dan yang terkecil adalah nol (0). Pemberian nilai pada content analysis yang terdiri dari 43 item indeks ISR tersebut tidak diukur untuk berapa kali jumlah kejadian untuk masing-masing item diungkapkan dalam satu periode tahunan, tetapi minimal satu kali pengungkapan indeks ISR dalam bentuk apapun telah diungkapkan, maka item tersebut dianggap telah ada dan diberi nilai (skor) 1. Apabila item tersebut tidak ditemukan diungkapan maka item tersebut akan diberikan nilai (skor) 0. Berikut ini tabel Islamic Social Reporting (ISR) Index:

Tabel 1. Islamic Social Reporting (ISR) Index

\begin{tabular}{|c|l|}
\hline A & Pendanaan Investasi \\
\hline 1 & Riba \\
\hline 2 & Gharar \\
\hline 3 & Zakat: \\
\hline & - Metode yang digunakan \\
\hline & - Jumlah zakat \\
\hline & - Penerima manfaat \\
\hline 4 & $\begin{array}{l}\text { Kewajiban atas keterlambatan pembayaran piutang dan } \\
\text { penghapusan piutang tak }\end{array}$ \\
\hline & tertagih \\
\hline 5 & Current Value Balance Sheet (CVBS) \\
\hline 6 & Value Added Statement (VAS) \\
\hline B & Produk dan Jasa \\
\hline 7 & Produk yang ramah lingkungan \\
\hline 8 & Status kehalalan produk \\
\hline
\end{tabular}




\begin{tabular}{|c|l|}
\hline 9 & Kualitas dan keamanan suatu produk \\
\hline 10 & $\begin{array}{l}\text { Keluhan konsumen/indikator yang tidak terpenuhi dalam } \\
\text { peraturan dan kode }\end{array}$ \\
\hline & sukarela (jika ada) \\
\hline C & Karyawan \\
\hline 11 & Sifat pekerjaan: \\
\hline & - Jam kerja \\
\hline & - Liburan \\
\hline & - Manfaat lain \\
\hline 12 & Pendidikan dan pelatihan/pengembangan sumber daya manusia \\
\hline 13 & Kesempatan yang sama \\
\hline 14 & Keterlibatan karyawan \\
\hline 15 & Kesehatan dan keselamatan kerja \\
\hline 16 & Lingkungan kerja \\
\hline 17 & $\begin{array}{l}\text { Karyawan khusus kelompok lain (cacat, mantan narapidana, } \\
\text { mantan pecandu }\end{array}$ \\
\hline 18 & narkoba) \\
\hline 18 & $\begin{array}{l}\text { Eselon yang lebih tinggi di perusahaan melakukan shalat } \\
\text { berjamaah dengan para }\end{array}$ \\
\hline & manajer tingkat yang lebih rendah dan menengah \\
\hline 19 & $\begin{array}{l}\text { Karyawan muslim diizinkan untuk melakukan shalat wajib } \\
\text { mereka selama waktu }\end{array}$ \\
\hline & dan puasa tertentu ramadhan pada hari kerja mereka \\
\hline 20 & Tempat yang tepat ibadah bagi karyawan \\
\hline D & Masyarakat \\
\hline 21 & Saddaqa/ donasi \\
\hline 22 & Wakaf \\
\hline 23 & Qardhassan \\
\hline 24 & Biaya sukarela \\
\hline 25 & Pendidikan: \\
\hline & - skema adopsi sekolah \\
\hline 26 & - beasiswa \\
\hline 27 & Lulusan kerja \\
\hline 28 & Kemerasi muda \\
\hline 29 & Kepedulian anak \\
\hline 30 & Amal/hadiah/kegiatan sosial \\
\hline 31 & $\begin{array}{l}\text { Mensponsori kesehatan masyarakat/proyek rekreasi/acara } \\
\text { budaya }\end{array}$ \\
\hline E & Lingkungan \\
\hline & \\
\hline
\end{tabular}




\begin{tabular}{|l|l|}
\hline 32 & Konservasi lingkungan \\
\hline 33 & Satwa liar yang terancam punah \\
\hline 34 & Pencemaran lingkungan \\
\hline 35 & Pendidikan lingkungan \\
\hline 36 & Produk lingkungan/proses yang terkait \\
\hline 37 & $\begin{array}{l}\text { Audit lingkungan/pernyataan verifikasi } \\
\text { independen/pemerintahan }\end{array}$ \\
\hline 38 & Sistem manajemen lingkungan / kebijakan \\
\hline F & Tata kelola perusahaan \\
\hline 39 & Status kepatuhan syariah \\
\hline 40 & Struktur kepemilikan: \\
\hline & - jumlah pemegang saham muslim dan kepemilikan sahamnya \\
\hline 41 & Papan struktur-muslim vs non-muslim \\
\hline 42 & Kegiatan terlarang: \\
\hline & - praktek monopoli \\
\hline & - penimbunan barang yang diperlukan \\
\hline & - manipulasi harga \\
\hline & - praktek bisnis penipuan \\
\hline & -judi \\
\hline 43 & Kebijakan anti-korupsi \\
\hline
\end{tabular}

Sumber : Raditya (2012)

Berikut ini rumus menghitung besarnya indeks ISR setelah scoring: Islamic Social Reporting Disclosure $=\quad$ Jumlah yang diungkapkan Jumlah yang seharusnya diungkapkan

Profitabilitas dapat dilihat dari komponen yang ada pada laporan keuangan, terutama laporan keuangan neraca dan laporan laba rugi profit margin on sales tahunan. Pengukuran profitabilitas menggun akan rasio dapat dilakukan dengan beberapa jenis rasio seperti return on Assets (ROA), profit margin, return on investment (ROI), return on equity (ROE), laba per lembar saham. Penelitian ini akan menggunakan return on Assets (ROA). Data return on Assets (ROA) akan didapatkan dari laporan keuangan perusahaan yang menjadi sampel dalam penelitian ini.

Profitabilitas $(\mathrm{ROA})=$ Laba bersih sebelum pajak 
Total Aset

Ukuran perusahaan dalam penelitian ini diukur dengan nilai total aset perusahaan. Total aset adalah total sumber daya yang dimiliki oleh perusahaan, sehingga perusahaan yang ukurannya besar pasti memerlukan total aset (sumber daya) yang banyak untuk menjalankan kegiatan usahanya. Maka dari itu, dalam penelitian ini total aset digunakan untuk mengukur ukuran perusahaan. Data total aset akan didapatkan dari laporan keuangan perusahaan yang menjadi sampel dalam penelitian ini. Total aset akan dibentuk menjadi logaritma natural (ln) agar bentuk data variabel total aset sama dengan bentuk variabel data yang lainnya.

Ukuran Perusahaan $=$ Ln $($ Total aset $)$.

Metode analisis data yang digunakan yatu analisis deskriptif dgunakan untuk memberikan gambaran mengenai deskripsi variabel-variabel yang digunakan dalam penelitian yang terdiri dari variabel independen, yaitu Ukuran Perusahaan, Profitabilitas dan ISR.

Setlah itu dilakukan Analisis regresi dummy bertujuan untuk memprediksi besar variabel dependen mengunakan variabel bebas, dimana data variabel dependen $(\mathrm{Y})$ adalah data kuantitatif dan data independent $(\mathrm{X})$ adalah data kategorial (Sujarweni, 2017). Rumus persamaan regresi dummy adalah :

$$
\mathrm{Y}=\mathrm{a}+\mathrm{b}_{1} \mathrm{X}_{1}+\mathrm{b}_{2} \mathrm{X}_{2}+\mathrm{e}
$$

Keterangan :

$\mathrm{Y}=$ Pengungkapan ISR

$\mathrm{A}=$ Konstanta

$\mathrm{X}_{1}=$ Profitabilitas

$\mathrm{X}_{2}=$ Ukuran Perusahaan

e $\quad$ Kesalahan regresi (regression error) 
Koefisien Determinasi $\left(\mathrm{R}^{2}\right)$ pada intinya mengukur seberapa jauh kemampuan model variabel independen dalam menerangkan variasi variabel dependen $^{29}$. Nilai koefisien determinasi adalah antara nol dan satu. Nilai $R^{2}$ yang kecil berarti kemampuan variabel-variabel independen dalam menjelaskan variasi variabel dependen amat terbatas. Nilai yang mendekati satu berarti variabel-variabel independen memberikan hampir semua informasi yang dibutuhkan untuk memprediksi variasi variabel dependen.

Uji ini digunakan untuk menunjukkan seberapa jauh pengaruh satu variabel independen secara individual dalam menerangkan variabel dependen. Dasar pengambilan keputusannya menggunakan model signifikan dengan alpha sebesar $5 \%(0,05)$, dengan ketentuan sebagai berikut :

Uji Statistik $t$ antara lain:

a. Jika signifikansi < 0,05, maka variabel independen secara parsial berpengaruh terhadap variabel dependen (Ha diterima, H0 ditolak).

b. Jika signifikansi $>0,05$, maka variabel independen secara parsial tidak berpengaruh terhadap variabel dependen (Ha ditolak, H0 diterima).

\section{Hasil dan Pembahasan}

Pasar modal syariah secara resmi diluncurkan pada tanggal 14 Maret 2003 bersamaan dengan penandatanganan MOU antara BAPEPAM-LK dengan Dewan Syariah Nasional - Majelis Ulama Indonesia (DSN - MUI). Walaupun secara resmi diluncurkan pada tahun 2003, namun instrumen pasar modal syariah telah hadir di Indonesia pada tahun 1997. Hal ini ditandai dengan peluncuran Danareksa Syariah pada 3 Juli 1997 oleh PT. Danareksa Investment Management. Selanjutnya Bursa Efek Indonesia bekerjasama dengan PT. Danareksa Investment Management meluncurkan Jakarta Islamic Index pada tanggal 3 Juli 2000 yang bertujuan untuk memandu investor yang ingin

29 Ghozali, Imam. 2014. Analisis Multivariate dengan Program SPSS. Universitas Diponegoro: Semarang, hlm. 65 
menanamkan dananya secara syariah. Dengan hadirnya indeks tersebut, maka para pemodal telah disediakan saham-saham yang dapat dijadikan sarana berinvestasi dengan penerapan prinsip syariah.

Jakarta Islamic Index dimaksudkan untuk digunakan sebagai tolok ukur (benchmark) untuk mengukur kinerja suatu investasi pada saham dengan basis syariah. Melalui index ini diharapkan dapat meningkatkan kepercayaan investor untuk mengembangkan investasi dalam ekuitas secara syariah. Jakarta Islamic Index terdiri dari 30 jenis saham yang dipilih dari saham-saham yang sesuai dengan Syariah Islam. Penentuan kriteria pemilihan saham dalam Jakarta Islamic Index melibatkan pihak Dewan Pengawas Syariah PT Danareksa Invesment Management.

Hasil analisis statistik menunjukkan bahwa Nilai rata-rata dari hasil uji statistik deskristif untuk variabel profitabilitas adalah sebesar 14,17. Nilai terendah variabel profitabilitas sebesar 11,15 dan nilai tertinggi sebesar 18,85. Hal ini berarti nilai standar deviasi yang mendekati nilai rata-rata dan ukuran penyebaran data yang semakin kecil. Hal ini berarti perusahaan sampel memiliki profitabilitas yang cenderung rendah dilihat dari nilai profitabilitas perusahaan sampel mendekati rata-rata dan variasinya semakin kecil.

Ukuran perusahaan yang diproksikan dengan Ln total aset untuk mengetahui nilai riil dari variabelnya. Nilai rata-rata Ln ukuran perusahaan negatif sebesar -0,04 atau Rp 9.235.942 (dalam juta). Standar deviasi 0,91 atau Rp 25.079.451 (dalam juta) yang berarti ukuran penyebaran data ukuran perusahaan ini cukup besar, hal ini didukung nilai standar deviasi yang semakin menjauhi nilai rata-rata dan ukuran penyebarannya semakin besar. Nilai terendah ukuran perusahaan sebesar -5,22 atau Rp 72.830 (dalam juta) dan nilai tertinggi ukuran perusahaan sebesar 1,30 atau Rp 18. 151.331 (dalam juta). Perusahaan yang menjadi sampel penelitian cenderung berukuran besar yang ditunjukkan dengan nilai tertinggi dan standar deviasi yang semakin besar dari nilai rata-rata. Nilai rata-rata ukuran perusahaan sebesar $\operatorname{Rp} \operatorname{Rp} 9.235 .942$ 
(dalam juta). Sedangkan standar deviasi sebesar Rp 25.079.451 (dalam juta). Hal itu mengindikasikan bahwa ukuran perusahaan sampel berada di atas rata-rata atau menjauhi rata-rata sehingga menunjukkan bahwa ukuran perusahaan cenderung berukuran besar.

Variabel indeks ISR, ukuran perusahaan, tipe industri, profitabilitas berdistribusi normal karena probabilitas $>0,05$. Langkah selanjutnya melakukan analisis dengan regresi linear. Variabel independen dalam penelitian ini adalah ukuran perusahaan, profitabilitas, tipe indsutri, umur perusahaan dan GCG. Sedangkan variabel independennya adalah ISR.

Tabel 2. Hasil Analisis Regresi Dummy

\begin{tabular}{|c|c|c|c|c|c|c|}
\hline & \multirow{2}{*}{ Model } & \multicolumn{2}{|c|}{$\begin{array}{c}\text { Unstandardized } \\
\text { Coefficients }\end{array}$} & \multirow{2}{*}{$\begin{array}{c}\begin{array}{c}\text { Standardized } \\
\text { Coefficients }\end{array} \\
\text { Beta }\end{array}$} & \multirow[b]{2}{*}{$\begin{array}{c}\mathrm{t} \\
\text { hitung }\end{array}$} & \multirow[b]{2}{*}{ Sig. } \\
\hline & & B & $\begin{array}{l}\text { Std. } \\
\text { Error }\end{array}$ & & & \\
\hline \multirow[t]{3}{*}{1} & Constan & 0,060 & 0,788 & - & 0,077 & 0,939 \\
\hline & $\begin{array}{l}\text { Profitabilitas } \\
(\mathrm{X} 2)\end{array}$ & 0,016 & 0,054 & 0,033 & 2,305 & 0,011 \\
\hline & Ukuran (X1) & 0,456 & 0,158 & 0,337 & 2,893 & 0,005 \\
\hline
\end{tabular}

Sumber : Hasil Pengolahan SPSS

Berdasarkan hasil analisis didapat persamaan regresi sebagai berikut: $\mathrm{Y}=0,060+0,016 \times 1+0,456 \times 2+\mathrm{e}$

Berdasarkan hasil analisis regresi berganda pada Tabel 1 dengan uji $t$ diperoleh hasil yang dapat dinyatakan :

a. Profitabilitas memiliki tingkat signifikansi (sig t) sebesar 0,005 dengan tanda positif. Nilai ini kurang dari a $(=0,05)$, maka hipotesis pertama yang menyatakan profitabilitas berpengaruh signifikan terhadap ISR diterima. Artinya, profitabilitas berpengaruh signifikan terhadap ISR pada industri manufaktur. 
b. Ukuran perusahaan memiliki tingkat signifikansi (sig $t$ ) sebesar 0,005. Nilai ini kurang dari a $(=0,05)$, maka hipotesis keduayang menyatakan ukuran perusahaan berpengaruh signifikan terhadap ISR ditolak. Artinya, ukuran perusahaan berpengaruh terhadap ISR pada industri manufaktur.

Berdasarkan hasil uji t maka koefisien-koefisien persamaan Regresi Dummy dapat diartikan sebagai berikut:

a. Profitabilitas secara statistik berpengaruh signifikan terhadap ISR artinya setiap peningkatan atau penurunan profitabilitas berpengaruh terhadap peningkatan ISR.

b. Ukuran perusahaan secara statistik tidak berpengaruh terhadap ISR artinya setiap peningkatan atau penurunan variabel ukuran perusahaan memiliki pengaruh terhadap peningkatan dan penurunan ISR.

Berdasarkan analisis data diketahui signifikansi F hitung sebesar 0,000 kurang dari level signifikansi 5\% $(0,000<0,05)$ maka menerima Ho dan menolak Ha. Artinya profitabilitas dan ukuran perusahaan berpengaruh signifikan terhadap ISR secara simultan.

a. Pengaruh Profitabilitas terhadap ISR

Hasil analisis regresi menunjukkan bahwa profitabilitas berpengaruh terhadap ISR. Artinya, Hipotesis dua $\left(\mathrm{H}_{2}\right)$ yang menyatakan bahwa profitabilitas berpengaruh signifikan terhadap ISR pada industri manufaktur yang terdaftar di JII, diterima. Hal itu menunjukkan bahwa peningkatan profitabilitas menyebabkan perusahaan melakukan tindakan ISR. Artinya, semakin tinggi laba perusahaan maka kecendurungan perusahaan melakukan ISR juga akan semakin tinggi.

Probabilitas berpengaruh terhadap ISR. Hal itu menunjukkan bahwa profitabilitas merupakan kemampuan perusahaan dalam menghasilkan keuntungan bersih setelah dipotong pajak. Semakin besar profitabilitas, maka kinerja perusahaan akan semakin produktif, sehingga akan meningkatkan 
kegiatan ISR. Hasil penelitian ini konsisiten dengan Othman et al. (2009) ${ }^{30}$ dan Raditya (2012) ${ }^{31}$ membuktikan bahwa profitabilitas mempunyai pengaruh positif signifikan terhadap tingkat pengungkapan ISR. Widiawati dan Raharja (2012) $)^{32}$ menemukan bahwa Profitabilitas berpengaruh positif dan signifikan terhadap ISR.

\section{b. Pengaruh Ukuran Perusahaan Terhadap ISR}

Hasil analisis regresi menunjukkan bahwa ukuran perusahaan tidak berpengaruh terhadap ISR. Artinya Hipotesis Satu $\left(\mathrm{H}_{1}\right)$ yang menyatakan bahwa ukuran perusahaan berpengaruh signifikan terhadap ISR pada industri manufaktur yang terdaftar di JII, ditolak. Hal itu menunjukkan bahwa ukuran perusahaan tidak menyebabkan perusahaan melakukan tindakan ISR.

Ukuran perusahaan berpengaruh signifikan terhadap ISR. Hal ini tejadi karena nilai total aset dari suatu perusahaan merupakan tolak ukur yang sesuai untuk menentukan besar kecilnya perusahaan, tetapi dilihat dari tingkat kemakmuran dari perusahaan tersebut. Hasil penelitian ini konsisten dengan Othman et al. (2009) ${ }^{33}$ dan Raditya (2012) ${ }^{34}$ menunjukkan bahwa ukuran perusahaan secara positif berpengaruh signifikan terhadap tingkat ISR. Widiawati dan Raharja (2012) 35 menemukan bahwa ukuran perusahaan berpengaruh signifikan dan positif terhadap ISR pada perusahaan manufaktur, perusahaan non-manufaktur, perusahaan yang menggunakan bank syariah maupun perusahaan yang tidak menggunakan bank syariah.

\footnotetext{
30 Op.Cit Othman et al. (2009)

31 Op.Cit. Raditya (2012)

32 Op.Cit. Widiawati dan Raharja (2012)

33 Op.Cit Othman et al. (2009)

34 Op.Cit. Raditya (2012)

35 Op.Cit. Widiawati dan Raharja (2012)
} 


\section{Kesimpulan dan Saran}

Berdasarkan hasil analisis data dapat disimpulkan bahwa profitabilitas secara statistik berpengaruh signifikan terhadap ISR artinya setiap peningkatan atau penurunan profitabilitas berpengaruh terhadap peningkatan ISR; ukuran perusahaan secara statistik berpengaruh terhadap ISR artinya setiap peningkatan atau penurunan variabel ukuran perusahaan memiliki pengaruh terhadap peningkatan dan penurunan ISR.

Saran yang dapat diajukan dalam penelitian ini adalah Bagi perusahaan, Perusahaan hendaknya melakukan peningkatan profitabilitas sehingga kegiatan ISR dapat terlaksana dengan lebih baik; bagi investor dan calon investor, Bagi investor dan calon investor diharapkan untuk selalu melakukan pertimbangan kondisi keuangan dalam berinvestasi dengan berdasarkan berbagai informasi tentang kondisi keuangan perusahaan. Hal ini perlu dilakukan agar investor tidak akan mengalami kerugian dalam melakukan investasi apabila perusahaan melakukan tindakaan ISR dan bagi peneliti selanjutnya dan akademisi, bahwa penelitian ini masih perlu ditindaklanjuti oleh peneliti selanjutnya untuk mendapatkan hasil penelitian yang lebih baik. 


\section{DAFTAR PUSTAKA}

Ariestia, 2010. Pengaruh Pengungkapan Corporate Social Responsibility (pengungkapan informasi CSR) Terhadap Profitabilitas Perusahaan. Jurnal Ekonomi. Fakultas Ekonomi. Universitas Jember.

Busyra Azheri, 2012. Corporate Social Responsibility; Dari Voluntary Menjadi Mandatory, Rajawali Pers, Jakarta, 2012.

Ghozali, Imam dan Chariri. 2007. Teori Akuntansi. Semarang : Badan Penerbit.

Ghozali, Imam. 2014. Analisis Multivariate dengan Program SPSS. Universitas Diponegoro: Semarang.

Gray, 1987. Social Report, Corporate Social Reporting Accounting \& Accountability. Prestice Journal: USA.

Halim, Abdul dan Hanafi, Mamduh M.2009. Analisis Laporan Keuangan. Edisi. 4. UPP STIM YKPN. Yogyakarta.

Handoko, Yunus. 2015. Implementasi Social and Environmental Disclosure dalam Perspektif Teoritis. Jurnal JIBEKA Volume 8 No 1 Februari.

Hanifah, M.Mahmud, 2002, Analisis Laporan Keuangan, Yogyakarta : YKPN.

Harahap. 2009. Pengaruh ISR, Ukuran Perusahaan dan Kepemilikan Saham Publik terhadap Profitabilitas pada Perusahaan yang terdaftar di JII. Univ Negeri Islam: Sumatera Utara.

Kasmir. 2008. Bank dan Lembaga Keuangan Lainnya. Edisi Revisi 2008. Jakarta: PT. Rajagrafindo Persada.

Kusuma, Tanjung dan Darlis. 2014 "Pengaruh corporate governance dan karakteristik perusahaan terhadap luas pengungkapan corporate social responsibility (CSR) di dalam Sustainability Report". JOM FEKON Vol. 1 No.2 Oktober.

Lewis, Linda and Jeffrey Unerman. 1999. Ethical Relativism: A Reason for Differences in Corporate Social Reporting. Critical Perspectives on Accounting. Vol. 10, p. 521-547.

Mardikanto, Totok. 2014. CSR (Corporate Social Responsibility). Bandung: Alfabeta 
Nadlifiyah, Ia Fajriyatun, 2016. Pengaruh Ukuran Perusahaan, Umur Perusahaan, Profitabilitas, Dan Likuiditas Terhadap Pengungkapan Islamic Social Reporting (Isr) Pada Bank Umum Syariah (BUS) Di Indonesia Tahun 2010-2014. Thesis, Universitas Airlangga.

Nur, Marzully dan Priantinah, Denies. 2012. Analisis Faktor-Fakor yang Mempengaruhi Pengungkapan Corporate Social Responsibility" Jurnal Nominal, Vol I, No I.

Othman et al. 2009. Islamic Social Reporting of Listed Companies in Malaysia. International Business and Economic Research Journal. Univ Teknomaya: Malaysia.

Raditya, Nurul Amalia Age. 2012. Analisis Faktor-faktor Yang Mempengaruhi Tingkat Pengungkapan Islamic Social Reporting (ISR) Pada Perusahaan Yang Terdaftar di Bursa efek Syariah (DES). Universitas Indonesia: Jakarta.

Ramadhani. 2016. Pengaruh Ukuran Perusahaan, Profitabilitas, Leverage dan Ukuran Dewan Pengawas Syariah terhadap Pengungkapan ISR. Jurnal Pekan: Jakarta.

Rosiana, dkk. 2015. Pengaruh Ukuran Perusahaan, Profitabilitas, Leverage, dan Islamic Governance Score terhadap Pengungkapan ISR. Jurnal Bisnis Manajeme Universitas Tirtayasa: Maluku.

Watts, R, L., and Zimmerman, J, L. 1986, Positive Accounting Theory. New. York, Prentice Hall.

Widiawati, Septi dan Raharja, Surya. 2012. Analisis Faktor-Faktor Yang Mempengaruhi Islamic Social Reporting Perusahaan-Perusahaan Yang Terdapat Pada Daftar Efek Syariah Tahun 2009-2011. Diponegoro Journal Of Accounting Volume 1, Nomor 2, Tahun 2012. 